\title{
30. OCEANIC PROCESSES INFLUENCING SST IN REGIONS RELATED TO THE ASIAN-AUSTRALIAN MONSOON SYSTEM
}

\author{
BO QIU \\ Department of Oceanography, University of Hawaii \\ Hawaii, USA \\ E-mail: bo@soest.hawaii.edu \\ YUKIO MASUMOTO \\ Japan Agency for Marine-Earth Science and Technology \\ Yokohama, Japan \\ E-mail:masumoto@jamstec.go.jp
}

\begin{abstract}
Variability associated with the Asian-Australian monsoon system has been recognized in recent years as resulting from air-sea coupled processes. This points to the importance of ocean dynamics that controls the time-varying sea surface temperature (SST) signals. Aside from the surface heat flux forcing, many oceanic processes can produce changes in SST in the Asian-Australian monsoon regions: lateral advection by oceanic mean/eddy flows, enhanced tidal mixing in shallow seas, variability in the thermocline depth induced either locally or remotely (via wave-guides) in the Pacific and Indian Oceans, wind-induced coastal upwelling, and salinity stratification related to the monsoonal rainfall and river runoff. This article reviews some of these oceanic processes on the basis of our understanding achieved in recent years.
\end{abstract}

\section{Introduction}

The tropical western Pacific and eastern Indian Oceans (Fig. 1) are regions under direct monsoonal wind forcing of the Maritime Continent. In these regions, sea surface temperatures (SSTs) are highest within the global oceans and changes in the SST are relatively weak (Fig. 2). Despite their small amplitudes, the subtle SST variations have been found to result in significant changes in the vigour of the monsoon and the weather patterns across the Indo-Pacific basin (e.g., Ashok et al. 2001; Neale and Slingo 2003; McBride et al. 2003). Indeed, as noted recently by Webster (2006), there is a paradigm shift in viewing the monsoon as being driven simply by land-ocean heating differences, to an appreciation that ocean dynamics are important, and, more recently, to the realization that the monsoon is a thoroughly air-sea coupled system.

\section{Western Pacific Ocean}

In the western tropical Pacific, important oceanic pathways from subtropics to tropics involve low-latitude western boundary currents (WBCs). The physics of these WBCs is extremely complex, and present climate model resolutions are commonly too coarse, and 
parameterizations too crude, to give confidence in the results of numerical experiments involving advection and mixing in this region. For a better understanding of the long-term changes in the western tropical Pacific and its roles in controlling the regional surface ocean heat budget, it is crucial to obtain accurate analyses of the cross-gyre exchanges that occur in the region. Specifically, the North Equatorial Current (NEC) encounters the Philippine coast and splits into the Kuroshio and the Mindanao Current (e.g., Toole et al. 1990; see Fig. 1 and Fig. 3). Part of the equatorward-flowing Mindanao Current transport contributes to the Indonesian Throughflow (ITF), bringing northern hemisphere-origin water, commonly fresh in salinity, into the Indonesian Seas and the eastern Indian Ocean. The bifurcation of the NEC and partitioning of the Mindanao Current is affected by remote forcing from the interior of the Pacific, from the north along the western boundary, and by local monsoonal wind and buoyancy forcing (Qiu and Lukas 1996; Kim et al. 2004). Being a low-latitude WBC, the Mindanao Current variability is also directly impacted by the presence of the Mindanao Dome, whose changes are in part induced by the intrinsic, nonlinear ocean dynamics (Masumoto and Yamagata 1991; Tozuka et al. 2002).

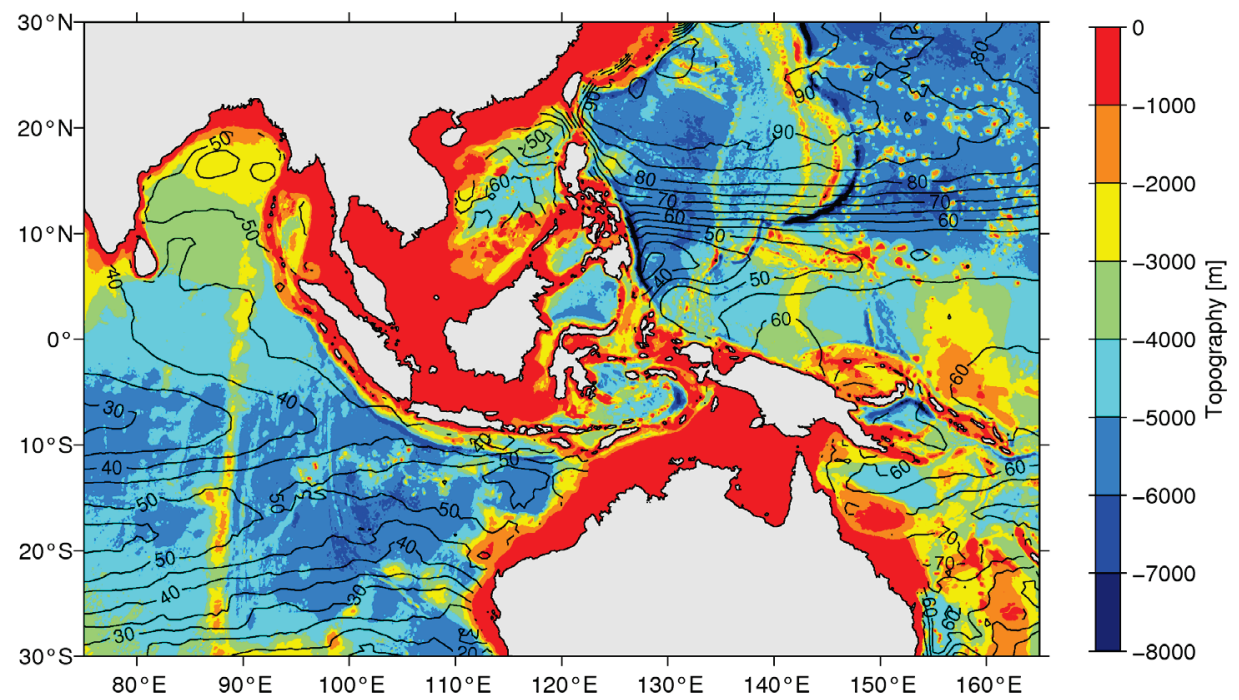

Figure 1. Regions of the western Pacific and eastern Indian Oceans under the influence of the Asian-Australian monsoons. Colored map shows the bathymetry based on Smith and Sandwell (1994) and black contours show the mean surface dynamic height (in cm) derived by Niiler et al. (2003).

A similar situation also exists in the tropical South Pacific where the westward-flowing South Equatorial Current splits upon reaching the Australian coast, into the northwardflowing North Queensland Current (NQC) and southward-flowing East Australian Current (Holbrook and Bindoff 1999; Kessler and Gourdeau 2007). The NQC connects to the New Guinea Coastal Current system which contributes ultimately to the water mass characteristics of the Pacific equatorial current systems and the ITF (e.g., Tsuchiya et al. 1989; Fukumori et al. 2004; Inoue and Welsh 1993; Talley and Sprintall 2005). The South Pacific circulation is 
more directly connected to the Equator than the North Pacific circulation and its changes have been argued to influence and modulate the equatorial background state upon which El Niño-Southern Oscillation (ENSO) evolves (Tsuchiya et al. 1989; Goodman et al. 2005). As noted in other articles of this publication, changes in the ENSO phase can indirectly impact the Asian-Australian monsoon system.

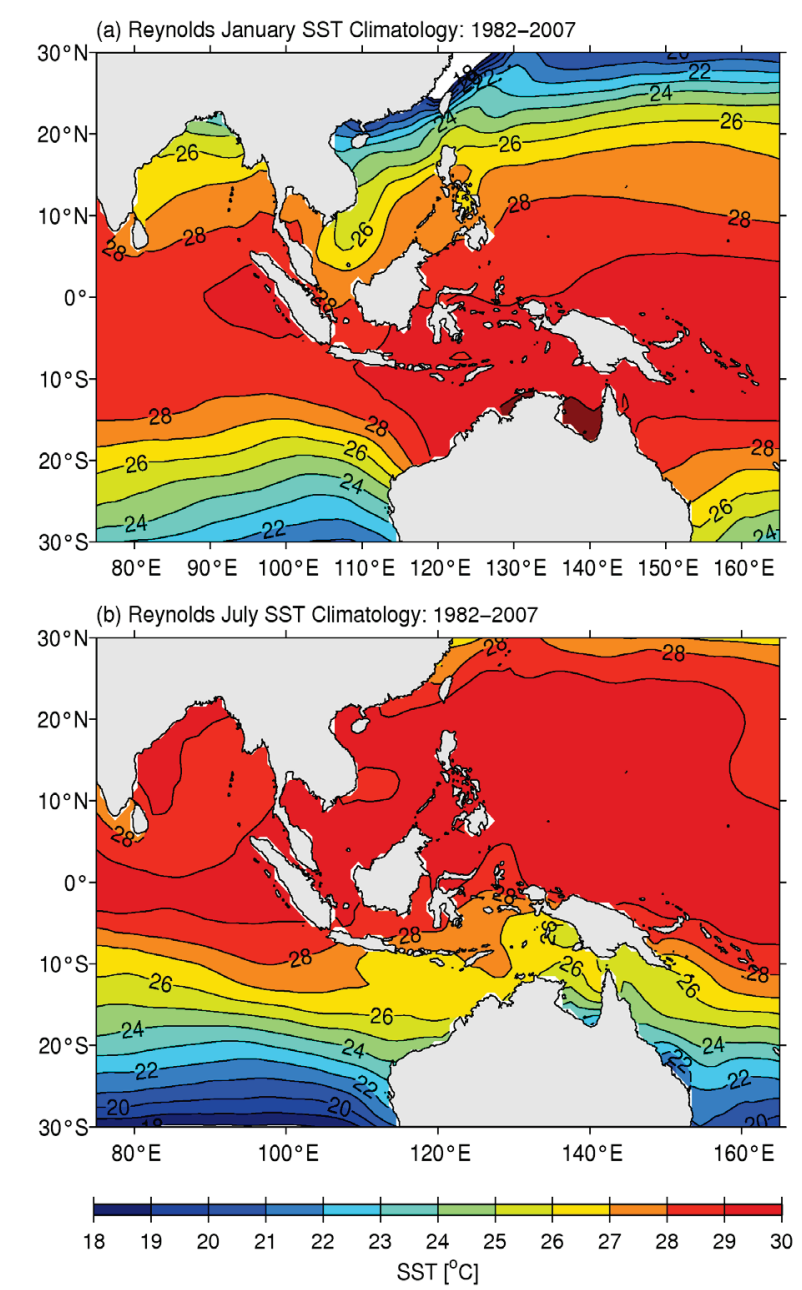

Figure 2. Climatological sea surface temperature distributions in (a) January, and (b) July. (based on Reynolds et al. 2002).

Compared to its counterpart in the northern hemisphere, ocean circulation in the tropical South Pacific is heavily affected by the complex regional topography. Presence of the Fiji Plateau, the Vanuatu and New Caledonia Archipelagos, the Solomon Island Chain, the Vitiaz and Solomon Straits and the St. Georges Channel induces narrow boundary currents and jets, providing an energy source for eddy-mean flow interaction, lateral mixing and water mass transformation (Webb 2000; Stanton et al. 2001; Gourdeau et al. 2008; Qiu et al. 2009). At 
present, a multi-national program named "SPICE" (Southwest Pacific Ocean Circulation and Climate Experiment; Ganachaud et al. 2007) is underway under the auspices of the International Climate Variability and Predictability (CLIVAR) Pacific Panel. As the SPICE program covers both the oceanic and atmospheric (specifically, the South Pacific Convergence Zone) variability in the southwest Pacific region, the results from SPICE will likely contribute significantly to the scientific goals of Asian Monsoon Years (AMY) and Asian-Australian Monsoon Panel (AAMP).

The hydrological cycle in the tropical western Pacific and eastern Indian Oceans is characterized by intense convective precipitation. In these regions, high precipitation leads to salinity-stratified barrier layers, where the surface isohaline layer becomes shallower than the isotherm layer (Lukas and Lindstrom 1991; Sprintall and Tomczak 1992). Salinity stratification is important in such a case because it controls the development of the surface ocean mixed layer (e.g., the wind-induced kinetic energy tends to be trapped within a thin mixed layer and the entrainment cooling is commonly reduced when a barrier layer is present) and dictates the amount of oceanic heat available for the overlying atmosphere. The surface freshwater fluxes in the western Pacific and eastern Indian Oceans undergo substantial variations on seasonal and interannual timescales associated with ENSO and regional monsoon systems. Changes in the freshwater fluxes, as well as fluctuations in oceanic advection, result in an observed sea surface salinity variation with a standard deviation of $0.4 \sim 1.4 \mathrm{psu}$ in the western tropical Pacific (Delcroix et al. 2005). What remains unclear is how this low-frequency change in sea surface salinity affects the regional mixed layer evolution and, ultimately, impacts the SST signals, upon which the atmospheric deep convection and heavy rainfall are sensitive.

A part of the convergent Mindanao and New Guinea western boundary currents in the western Pacific feeds the ITF westward through the Indonesian Seas, entering the eastern Indian Ocean between Australia and the Indonesian Archipelagos. Despite its significance to the regional and global climate, the mass, heat, and freshwater transports of the ITF are still poorly known, and their variability is high, albeit based on limited observations (Gordon 2005). Coupled and uncoupled general circulation model (GCM) studies, with the Indonesian Archipelagos open vs. closed, have indicated that the ITF affects both the Indian Ocean SST patterns and the Asian-Australian monsoon system (e.g., Wajsowicz 2002; Jochum and Potemra 2008). The ITF may also be involved in ENSO and Indian Ocean dipole (IOD) mode evolution, as they affect the variability of the heat budget of the western tropical Pacific and the eastern Indian Oceans on climate time scales. At present, a concerted, multi-national, in situ measurement program called "INSTANT" (International Nusantara Stratification and Transport) has just been completed (Gordon 2005) and the observational results are being quantified to clarify how regional SST changes are related to the oceanic advection, eddy mixing, and surface wind and buoyancy forcing.

A potentially important process that influences SST in the Maritime Continent is the South China Sea Throughflow (SCSTF), which involves inflow of cold, salty water through the Luzon Strait and outflow of warm, fresh water through other straits along the South China Sea (Qu et al. 2006). Preliminary model experiments also suggest that the SCSTF can reduce 
the ITF heat transport by as much as $47 \%$ (Tozuka et al. 2007), thus having a potential impact on heat distribution in the Maritime Continent and its adjoining tropical Indian and Pacific Oceans.

\section{Eastern Indian Ocean}

In the Indian Ocean, the warm water pool is located in the eastern half of the basin (Fig. 2). Most of the SST variability in this region is more or less affected by atmosphere-ocean interactions, in which the Asian-Australian monsoons play important roles in developing energy and material fluxes between the two mediums and ocean circulation systems. Although the region is far apart from the western boundary current systems both in the Pacific and Indian Oceans, the currents in the eastern Indian Ocean are as complex as the western Pacific (Fig. 3), mainly due to the direct influences of such monsoonal wind forcing (see a comprehensive review by Schott and McCreary 2001; Schott et al. 2009; and references therein). The surface currents in the northern hemisphere including the Bay of Bengal are characterized by seasonally reversing monsoon currents, with northeastward (southwestward) flows during boreal summer (winter) (e.g., Cutler and Swallow 1984; Vinayachandran et al. 1999). Heat and mass transport responsible for the SST variability in this region are determined partly by the monsoon currents. While in the southern hemisphere, the ITF makes the circulation quite unique to this particular region (Tomczak and Godfrey 1994). The ITF brings warm western Pacific equatorial water masses into the southeastern Indian Ocean, thus creating a rather large meridional pressure gradient. This in turn drives eastward geostrophic currents south of the ITF latitude and they converge into the boundary area off western Australia to generate southward eastern boundary current known as the Leeuwin Current, which flows against the prevailing northward winds over the region (e.g., McCreary et al. 1986; Godfrey and Weaver 1991; Hirst and Godfrey 1993). Because of this unusual current system, the SST off the northwestern coast of Australia is warmer than those in similar locations in the different ocean basins, and strongly influences the Australian monsoon system.

Superimposed on these mean and seasonal circulations are strong eastward surface jets, often referred to as Wyrtki jets, along the equator twice a year during the monsoon transition seasons of April/May and October/November (Wyrtki 1973). This semiannual variability is associated with the thermocline variability via radiation of the equatorial Kelvin waves, which contribute to zonal mass and heat re-distribution within the equatorial band, thus affecting the SST variability (Han et al. 1999). Subsequent propagation of the Kelvin waves, along the coasts of Indonesia to the south and of Thailand and countries further north in the Bay of Bengal, produce upper-layer heat content anomalies in areas remote from the equatorial forcing region ( $\mathrm{Yu}$ et al. 1991; Potemra et al. 1991). One interesting example can be found in a relatively small region off the southwestern coast of India, known as Laccadive High (Bruce et al. 1994), where the maximum SST develops during the boreal winter/spring associated with low salinity water intrusion from the Bay of Bengal, causing the barrier layer in the upper ocean to absorb more heat in the surface layer (Masson et al. 2005). It has been 
shown by Masson et al. (2005) that such an SST anomaly, though small in magnitude, tends to create earlier onset of the Asian monsoon system.

The semiannual Kelvin waves associated with Wyrtki jets also propagate to the southeast along the southern coasts of Sumatra, Java, and the Lesser Sunda Islands (e.g., Clarke and Liu 1993; Yamagata et al. 1996). Part of this wave energy penetrates into the Indonesian Seas through the Lombok Strait, influencing the variability in the upper-layer conditions within the archipelago, and possibly affecting the SST (e.g., Sprintall et al. 2000; Ffield et al. 2000). In addition, recent observational and modeling studies reveal that the Kelvin wave propagation can also be seen on an intraseasonal time-scale, which is generated in the equatorial Indian Ocean by the atmospheric intraseasonal variations, including the Madden-Julian Oscillation (e.g., Qiu et al. 1999; Iskandar et al. 2005).

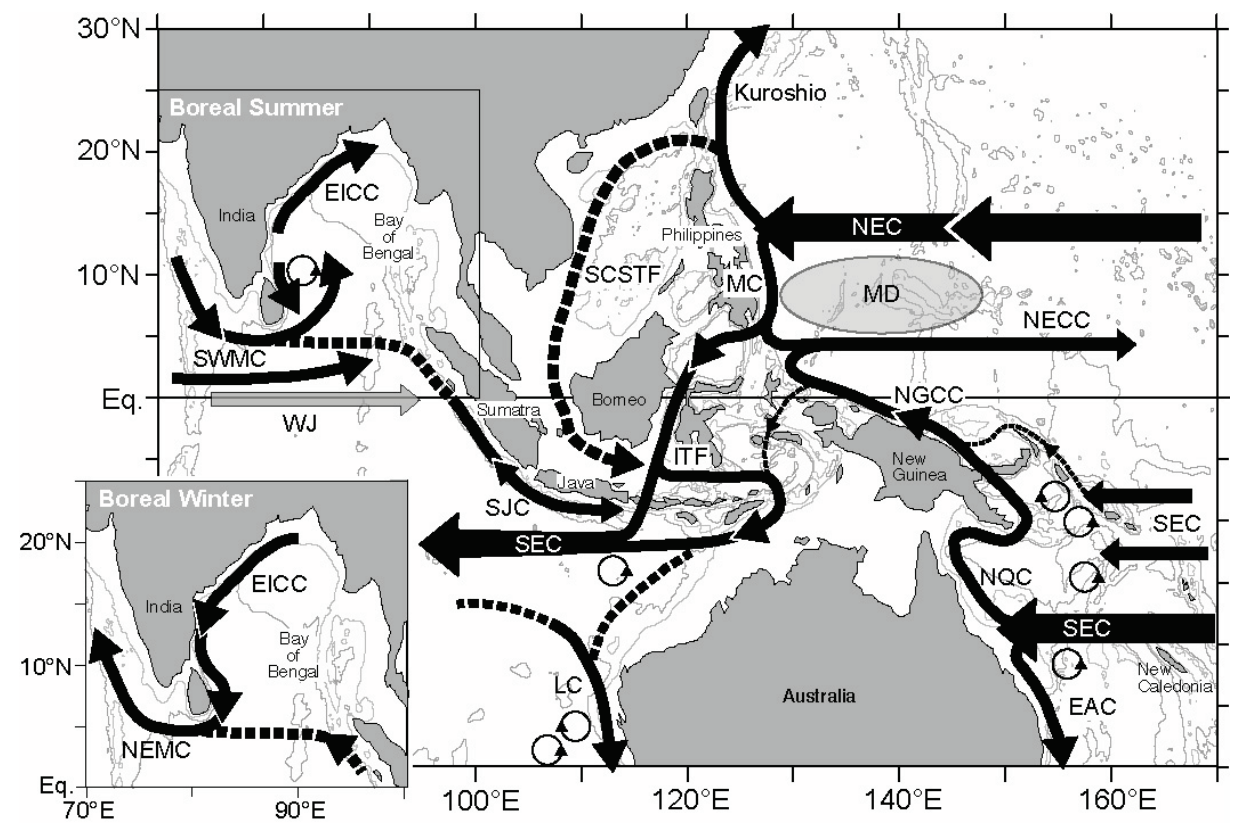

Figure 3. A schematic view of major surface current systems in the western tropical Pacific and eastern Indian Oceans, including those in the Maritime Continent. For the northern Indian Ocean, the currents in the boreal summer are indicated in the main figure, with a separate figure for the boreal winter currents. Current systems indicated by abbreviations are the North Equatorial Current (NEC), Mindanao Current (MC), North Equatorial Countercurrent (NECC), New Guinea Coastal Current (NGCC), South Equatorial Current (SEC), North Queensland Current (NQC), East Australian Current (EAC), Indonesian Throughflow (ITF), South China Sea Throughflow (SCSTF), South Java Current (SJC), Leeuwin Current (LC), East Indian Coastal Current (EICC), Southwest Monsoon Current (SWMC), and Northeast Monsoon Current (NEMC). Wyrtki jets (WJ) appear in April/May and September/October, while the Mindanao Dome (MD) develops during boreal winter.

Basin scale air-sea coupled climate modes in the tropics are another key phenomena directly affecting the SST variability in the Indian Ocean on interannual time-scales. With the standard statistical analyses to the SST variability, a basin-scale mono-pole structure is detected as the most dominant pattern of the interannual variability, which has strong 
association with ENSO in the Pacific Ocean (e.g., Chambers et al. 1999; Lau and Nath 2003). In most cases the warming (cooling) of the Indian Ocean SST occurs a few months after the height of El Niño (La Niña) event in the tropical Pacific Ocean. Such SST variability generated mainly by atmospheric bridging over the Indo-Pacific sector causes an anomalous condition of Asian and Australian monsoons.

The IOD mode is another important phenomenon appearing over the eastern Indian Ocean warm pool region. IOD is normally characterized by anomalous cooling of SST in the southeastern equatorial Indian Ocean and anomalous warming of SST in the western equatorial Indian Ocean, and such conditions are often referred to as positive IOD events (Saji et al. 1999; Webster et al. 1999). Associated with these SST changes, the atmospheric convection that is normally situated over the eastern Indian Ocean warm pool shifts to the west and brings heavy rainfall over east Africa and severe droughts/forest fires over the Indonesian/Australian region. The name IOD represents the zonal dipole structures not only in the SST field but also in other various coupled ocean-atmosphere parameters such as outgoing longwave radiation (OLR) and sea surface height anomalies (e.g., Yamagata et al. 2002). The canonical positive IOD event starts around May with a small patch of the negative SST anomaly in the eastern tropical Indian Ocean along the southern coast of Sumatra and Java. Stronger than normal southeasterly surface wind anomaly is associated with these SST variations, and the easterly wind anomaly penetrates into the equatorial region, creating upwelling-favorable conditions in the upper ocean, thus developing the negative SST anomaly. The westward shift of the warm water region enhances the easterly winds along the equator, activating Bjerknes feedback mechanism over the Indian Ocean.

The negative IOD event, which is, in effect, the reversal of the positive IOD event, has the warmer SST, deeper thermocline, and stronger atmospheric convections over the eastern Indian Ocean. This negative event increases precipitation over Australia and Indonesia, while dryer conditions develop over the western Indian Ocean. It is thought that the IOD events provide interannual modulation to the background state that result in abnormal conditions in monsoon and other related variability (e.g., Ashok et al. 2001, 2004; Guan et al. 2003).

The tropical Southwest Indian Ocean (SWIO) has emerged recently as highly climatically relevant (e.g., Xie et al. 2002). Along the thermocline ridge in SWIO, ocean dynamics is shown to be important for interannual SST anomalies, which in turn affect local atmospheric convection, tropical cyclones, and the onset of the Indian summer monsoon. More recently, $\mathrm{Du}$ et al. (2009) show that the dynamically-induced SWIO warming induces a basin-wide wind pattern and helps prolong the basin-wide warming via wind-induced latent heat flux. The long-lasting basin-wide warming of the tropical Indian Ocean is not merely a passive response to El Niño but exerts marked influences on the summer monsoons over the Northwest Pacific and East Asia (Xie et al. 2009).

\section{References}

Ashok, K., Z. Guan, and T. Yamagata, 2001: Impact of the Indian Ocean Dipole on the relationship between Indian Ocean monsoon rainfall and ENSO. Geophys. Res. Lett., 28, 4499-4502. 
Ashok K., Z. Guan, N. H. Saji, and T. Yamagata, 2004: On the individual and combined influences of the ENSO and the Indian Ocean dipole on the Indian summer monsoon. J. Climate, 17, 31413154.

Bruce, J. G., D. R. Johnson, and J. C. Kindle, 1994: Evidence for eddy formation in the eastern Arabian Sea during the northeast monsoon. J. Geophys. Res., 99, 7651-7664.

Chambers, D. P., B. D. Tapley, and R. H. Stewart, 1999: Anomalous warming in the Indian Ocean coincident with El Niño. J. Geophys. Res., 104, 3035-3047.

Clarke, R. A. and X. Liu, 1993: Observations and dynamics of semiannual and annual sea levels near the eastern equatorial Indian Ocean boundary. J. Phys. Oceanogr., 23, 386-399.

Cutler, A. N. and J. C. Swallow, 1984: Surface currents in the Indian Ocean (to 25S, 100E). Rep. 187, Inst. of Oceanogr. Sci., Wormley, England, 42pp.

Delcroix, T., M. J. McPhaden, A. Dessier, and Y. Gouriouu, 2005: Time and space scales for sea surface salinity in the tropical oceans. Deep-Sea Res., 52, 787-813.

$\mathrm{Du}$, Y., S.-P. Xie, G. Huang, and K. Hu, 2009: Role of air-sea interaction in the long persistence of El Niño-induced North Indian Ocean warming. J. Climate, 22, 2023-2038.

Ffield, A. L., K. Vranes, A. L. Gordon, R. D. Susanto, and S. L. Garzoli, 2000: Temperature variability within Makassar Strait. Geophys. Res. Lett., 27, 237-240.

Fukumori, I., T. Lee, B. Cheng, and D. Menemenlis, 2004: The origin, pathway and destination of the Niño-3 water estimated by a simulated passive tracer and its adjoint. J. Phys. Oceanogr., 34, 582604.

Ganachaud, A. and Co-authors, 2007: Southwest Pacific Ocean Circulation and Climate Experiment (SPICE) - Part I. Scientific background. CLIVAR Pub. No.111, NOAA OAR Special Report, NOAA/OAR/PMEL, Seattle, WA, 37pp.

(http://eprints.soton.ac.uk/46331/01/111_SPICEscienceplan.pdf)

Godfrey, J. S. and A. J. Weaver, 1991: Is the Leeuwin Current driven by Pacific heating and winds? Prog. Oceanogr., 27, 225-272.

Goodman, P. J., W. Hazeleger, P. de Vries, and M. Cane, 2005: Pathways into the equatorial undercurrent: A trajectory analysis. J. Phys. Oceanogr., 35, 2134-2151.

Gordon, A. L., 2005: Oceanography of the Indonesian Seas and their throughflow. Oceanogr., 18, 1427.

Gourdeau, L., W. S. Kessler, R. E. Davis, J. Sherman, C. Maes, and E. Kestenare, 2008: Zonal jets entering the Coral Sea. J. Phys. Oceanogr., 38, 715-725.

Guan, Z., K. Ashok, and T. Yamagata, 2003: Summertime response of the tropical atmosphere to the Indian Ocean dipole sea surface temperature anomalies. J. Meteor. Soc. Japan, 81, 533-561.

Han, W., J. P. McCreary, D. L. T. Anderson, and A. J. Mariano, 1999: On the dynamics of the eastward surface jets in the equatorial Indian Ocean. J. Phys. Oceanogr., 29, 2191-2209.

Hirst, A. C. and J. S. Godfrey, 1993: The role of Indonesian Throughflow in a global ocean GCM. $J$. Phys. Oceanogr., 23, 1057-1086.

Holbrook, N. J. and N. L. Bindoff, 1999: Seasonal temperature variability in the upper Southwest Pacific Ocean. J. Phys. Oceanogr., 29, 366-381.

Inoue, M. and S. Welsh, 1993: Modeling seasonal variability in the wind-driven upper-layer circulation in the Indo-Pacific region. J. Phys. Oceanogr., 23, 1411-1436.

Iskandar, I., W. Mardiansyah, Y. Masumoto, and T. Yamagata, 2005: Intraseasonal Kelvin waves along the Southern coast of Sumatra and Java. J. Geophys. Res., 110, C04013, doi:10.1029/ 2004JC002508. 
Jochum, M. and J. Potemra, 2008: Sensitivity of tropical rainfall to Banda Sea diffusivity in the community climate system model. J. Climate, 21, 6445-6454.

Kessler, W. S. and L. Gourdeau, 2007: The annual cycle of circulation of the southwest subtropical Pacific, analyzed in an Ocean GCM. J. Phys. Oceanogr., 37, 1610-1627.

Kim, Y. Y., T. Qu, T. Jensen, T. Miyama, H. Mitsudera, H.-W. Kang, and A. Ishida, 2004: Seasonal and interannual variability of the North Equatorial Current bifurcation in a high-resolution OGCM. J. Geophys. Res., 109, C03040, doi:10.1029/2003JC002013.

Lau, N. C. and M. J. Nath, 2003: Atmosphere-ocean variations in the Indo-Pacific sector during ENSO episodes. J. Climate, 16, 3-20.

Lukas, R. and E. Lindstrom, 1991: The mixed layer of the western equatorial Pacific Ocean. $J$. Geophys. Res., 96, 3343-3357.

Masson, S., J.-J. Luo, G. Madec, J. Vialard, F. Durand, S. Gualdi, E. Guilyardi, S. Behera, P. Delecluse, A. Navarra, and T. Yamagata, 2005: Impact of barrier layer on winter-spring variability of the southeastern Arabian Sea. Geophys. Res. Lett., 32, L07703, doi:10.1029/2004GL021980.

Masumoto, Y. and T. Yamagata, 1991: Response of the western tropical Pacific to the Asian winter monsoon: The generation of the Mindanao Dome. J. Phys. Oceanogr., 21, 1386-1398.

McBride, J., M. Haylock, and N. Nicholls, 2003: Relationships between the Maritime Continent heat source and the El Niño-Southern Oscillation phenomenon. J. Climate, 16, 2905-2914.

McCreary, J. P., S. R. Shetye, and P. K. Kundu, 1986: Thermohaline forcing of eastern boundary currents: with application to the circulation off the west coast of Australia. J. Mar. Res., 44, 71-92.

Neale, R. and J. Slingo, 2003: The Maritime Continent and its role in the global climate: A GCM study. J. Climate, 16, 834-848.

Niiler, P. P., N. A. Maximenko, G. G. Panteleev, T. Yamagata, and D. B. Olson, 2003: Near-surface dynamical structure of the Kuroshio Extension. J. Geophys. Res., 108, doi:10.1029/2002JC 001461.

Potemra, J. T., M. E. Luther, and J. J. O’Brien, 1991: The seasonal circulation of the upper ocean in the Bay of Bengal. J. Geophys. Res., 96, 12,667-12,683.

Qiu, B. and R. Lukas, 1996: Seasonal and interannual variability of the North Equatorial Current, the Mindanao Current and the Kuroshio along the Pacific wetsern boundary. J. Geophys. Res., 101, $12,315-12,330$.

Qiu, B., M. Mao, and Y. Kashino, 1999: Intraseasonal variability in the Indo-Pacific throughflow and the regions surrounding the Indonesian seas. J. Phys. Oceangr., 29, 1599-1618.

Qiu, B., S. Chen, and W. S. Kessler, 2009: Source of the 70-day mesoscale eddy variability in the Coral Sea and the North Fiji Basin. J. Phys. Oceanogr., 39, 404-420.

Qu, T., Y. Du, and H. Sasaki, 2006: South China Sea Throughflow: A heat and freshwater conveyor. Geophys. Res. Lett., 33, doi:10.1029/2006GL028350.

Reynolds, R. W., N. A. Rayner, T. M. Smith, D. C. Stokes, and W. Wang, 2002: An improved in situ and satellite SST analysis for climate. J. Climate, 15, 1609-1625.

Saji, N. H., B. N. Goswami, P. N. Vinayachandran, and T. Yamagata, 1999: A dipole mode in the tropical Indian Ocean. Nature, 401, 360-363.

Schott, F. A. and J. P. McCreary, 2001: The monsoon circulation of the Indian Ocean. Prog. Oceanogr., 51, 1-123.

Schott, F. A., S.-P. Xie, and J. P. McCreary, 2009: Indian Ocean circulation and climate variability. Rev. Geophys., 47, RG1002, doi:10.1029/2007RG000245.

Smith, W. H. F. and D. T. Sandwell, 1994: Bathymetric prediction from dense altimetry and sparse 
shipboard bathymetry. J. Geophys. Res., 99, 21,803-21,824.

Sprintall, J. and M. Tomczak, 1992: Evidence of the barrier layer in the surface layer of the tropics. $J$. Geophys. Res., 97, 7305-7316.

Sprintall, J., A. L. Gordon, R. Murtugudde, and R. D. Susanto, 2000: A semiannual Indian Ocean forced Kelvin wave observed in the Indonesian seas in May 1997. J. Geophy. Res., 105, 17,21717,230 .

Stanton, B., D. Roemmich, and M. Kosro, 2001: A shallow zonal jet south of Fiji. J. Phys. Oceanogr., 20, 307-318.

Talley, L. and J. Sprintall, 2005: Deep expression of the Indonesian Throughflow: Indonesian intermediate water in the South Equatorial Current. J. Geophys. Res., 110, C10009, doi:10.1029/ 2004JC002826.

Tomczak, M. and J. S. Godfrey, 1994: Regional Oceanography: An introduction. Pergamon Press, 432pp.

Toole, J. M., R. C. Millard, Z. Wang, and S. Pu, 1990: Observations of the Pacific North Equatorial Current bifurcation at the Philippine coast. J. Phys. Oceanogr., 20, 307-318.

Tozuka, T., T. Kagimoto, Y. Masumoto, and T. Yamagata, 2002: Simulated multiscale variations in the western tropical Pacific: The Mindanao Dome revisited. J. Phys. Oceanogr., 32, 1338-1359.

Tozuka, T., T. Qu, and T. Yamagata, 2007: Dramatic impact of the South China Sea on the Indonesian Throughflow. Geophys. Res. Lett., 34, doi:10.1029/2007GL030420.

Tsuchiya, M., R. Lukas, R. A. Fine, E. Firing, and E. Lindstrom, 1989: Source waters of the Pacific Undercurrent. Prog. Oceanogr., 23, 101-147.

Vinayachandran, P. N., Y. Masumoto, T. Mikawa, and T. Yamagata, 1999: Intrusion of the southwest monsoon current into the Bay of Bengal. J. Geophys. Res., 104, 11,077-11,085.

Wajsowicz, R. C., 2002: Air-sea interaction over the Indian Ocean due to variations in the Indonesian Throughflow. Climate Dyn., 18, 437-453.

Webb, D. J., 2000: Evidence for shallow zonal jets in the South Equatorial Current region of the southwest Pacific. J. Phys. Oceanogr., 30, 706-720.

Webster, P. J., A. M. Moore, J. P. Loschnigg, and R. R. Leben, 1999: Coupled ocean-atmosphere dynamics in the Indian Ocean during 1997-98. Nature, 401, 356-359.

Webster, P. J., 2006: The coupled monsoon system. The Asian Monsoon, Chap. 1. (Ed.) B. Wang, Springer-Praxis, 3-66.

Wyrtki, K., 1973: An equatorial jet in the Indian Ocean. Science, 181, 262-264.

Xie, S.-P., H. Annamalai, F. A. Schott, and J. P. McCreary, 2002: Structure and mechanisms of South Indian Ocean climate variability. J. Climate, 15, 864-878.

Xie, S.-P., K. Hu, J. Hafner, H. Tokinaga, Y. Du, G. Huang, and T. Sampe, 2009: Indian Ocean capacitor effect on Indo-western Pacific climate during the summer following El Nino. J. Climate, 22, 730-747.

Yamagata, T., K. Mizuno, and Y. Masumoto, 1996: Seasonal variations in the equatorial Indian Ocean and their impact on the Lombok Throughflow. J. Geophys. Res., 101, 12,465-12,473.

Yamagata, T., S. K. Behera, S. A. Rao, Z. Guan, K. Ashok, and H. N. Saji, 2002: The Indian Ocean Dipole: a physical entity. CLIVAR Exchanges, 7(2), 15-18.

Yu, L., J. J. O'Brien, and J. Yang, 1991: On the remote forcing of the circulation in the Bay of Bengal. J. Geophys. Res., 96, 20,440-20,454. 